\title{
The evolved landscape of ePortfolios: Current values and purposes of academic teachers and curriculum designers
}

\author{
Jennifer Rowley ${ }^{1}$, Jennifer Munday ${ }^{2}$ \\ jennnifer.rowley@sydney.edu.au; imunday@csu.edu.au \\ ${ }^{1}$ The University of Sydney, ${ }^{2}$ Charles Sturt University
}

\begin{abstract}
As ePortfolios are increasingly being used in universities to help develop self-reflective practitioners, academic teachers and students need to develop the skills and processes required to implement them. During 2015, a series of webinars was presented by a crossuniversity team to provide professional development for academic teachers, curriculum designers and other staff interested in initiating or extending ePortfolio learning in their institutions. A survey was conducted with participants to gauge the depth of understanding and use of ePortfolios in degree programs. The survey aimed to clarify participants' perception of the value of ePortfolio tools in Australian universities, and to identify future directions for developing knowledge and learning related to ePortfolios. Through the survey questions participants were able to provide information anonymously about their knowledge and use of ePortfolios. Respondents were also invited to be interviewed. Nine interviews, conducted in 2016, explored ePortfolio-users' opinions of the learning tool. The results indicate that teachers' use of the ePortfolio as a learning tool has evolved beyond that reported in the current literature. Furthermore, when used for reflection, assessment and documenting professional standards, the ePortfolio tool contributes to the students' development of skills required to transition to future careers.
\end{abstract}

Keywords: ePortfolios, reflective practice, digital literacies, higher education

\section{Introduction and background}

This paper reports on a study designed to support the evolution of the well-documented ePortfolio as a learning tool. The study consisted of two stages: an online survey followed by participant interviews. The data from the study reports increased confidence in those who use ePortfolios in their entirety, rather than being limited to the purpose of a showcase or presentation, which were the original uses for hardcopy portfolios.

ePortfolios are increasingly used in universities to help develop self-reflective practitioners. Parkes, Dredger and Hicks (2013) say this increase in usage is due to greater accountability for student learning. Boesch, Reynolds and Patton (2016) suggest that the main reason for the increase in usage is the pressure on higher education institutions for student accountability, arguing for the capacity of ePortfolios to demonstrate the education of the whole person, rather than discipline by discipline, by providing a platform to demonstrate the interconnection of knowledge (p. 443).

At the same time, Herring and Notar (2011), in describing a successful ePortfolio implementation, emphasised the need for the cooperative effort of professors, administration 
staff, teachers and students, all of whom required training, and for implementation strategies. However, Ring and Ramirez (2012) remind us that in addition to preparation for implementation, time, discussion and repetition are needed with academic assessors, in order to manage the assessment of ePortfolios.

This resonates with the experience of the authors of this paper who have embedded ePortfolios in degree programs at their respective universities. One of the universities serves a large urban population and the other is rural with several campuses located hundreds of kilometres from each other. Both institutions work heavily in the online space, but for different purposes. The urban university emphasises the growing need for an individual to create a virtual presence that can be shared broadly with several stakeholders, including prospective employers. The rural university also encourages the creation of an online sharable resource, but the majority of its students are studying in the online space to begin with, or in a blended mixed mode of on-campus and online. The learning design for the ePortfolio in each institution reflects the current drive for graduates to account for professional skills to accrediting bodies as they cross the threshold to their chosen profession. Research projects were undertaken within these institutions to ascertain the effectiveness of ePortfolio learning and thinking and its value to students, graduates and prospective employers, particularly in regard to the evidence of the emergence of a growing professional 'self' by the creator of the ePortfolio (Rowley \& Munday, 2014).

From 2011 to 2014 an investigation of ePortfolios for creative arts, music and arts students in Australian universities was funded by the Australian Government's Office for Learning and Teaching. The aim of this project was primarily to determine the effects of student created ePortfolios in teaching music and other creative and performing Arts students (OLT, 2016). The outcomes of this multi-institutional project provided evidence that the ePortfolio process contributed to Arts students' identities, the enhancement of learning in a technology environment and highlighted the impact on teachers and teaching, through ePortfolios (Bennett, Rowley, Dunbar-Hall, Hitchcock, \& Blom, 2016).

One of the major outcomes from this earlier ePortfolio project was the finding that academic teachers and curriculum designers wanted to learn more about ePortfolio processes and platforms, in order to learn ways to introduce and/or embed them into their university degree programs. As a result, an extension project was funded by the same granting body to explore the needs of staff to better manage the implementation of portfolios across a range of disciplines in higher education. This further funding supported the development of a series of webinars and other professional development artefacts, which were presented by a crossuniversity team. The webinar presenters were all working extensively with ePortfolios in four Australian universities: two urban, The University of Sydney (which led the project) and The University of Western Sydney; one regional, The University of Canberra; and one regional and rural, Charles Sturt University. The webinars and the creation of the professional development artefacts were planned across the 2015 academic year to include face-to-face seminars in each institution together with virtual attendance from the others, and also included interested attendees from other Australian universities. The main aim was to provide professional development for academic teachers and curriculum designers interested in initiating or extending ePortfolio learning in their institutions, and each progressive seminar/webinar responded to, and extended, the learning of the attendees from the previous session. Both projects resulted in data contributing to an open source website (ePortfolioassist.com.au) for use across all stages of ePortfolio practice for teachers, students and institutions. ePortfolio practices to support and enhance quality learning and teaching were defined, refined and validated through both of these projects (OLT, 2016).

Due to the strong positive response to the webinar series, the webinar leaders were interested in finding out more about participants' understanding of ePortfolios and the current 'state of play' for those academic leaders interested in, or currently involved in, implementing the processes of ePortfolios into Australian higher education degree programs. After gaining ethics approval, participants were invited to complete a survey and to volunteer for an

Rowley, J. \& Munday, J, (2018). The evolved landscape of ePortfolios: Current values and purposes of academic teachers and curriculum designers. Journal of Teaching and Learning for Graduate Employability, 9(1), 3-22. 
interview. The analysis of the data shows that there is a changing landscape around ePortfolio practices across the Australian higher education sector. The recent published literature has not indicated a dramatic change in the use or prevalence of ePortfolios, and yet this paper provides evidence that the scene has indeed seen a change in staff attitudes and use.

\section{Literature review}

It is apparent in more recent and robust literature that a move from the simple to a more complex application of ePortfolio practice is emerging. The literature reviewed for this project includes research in: the history of the ePortfolio; the need for continued and further professional development of higher education staff in designing and implementing curriculum that includes embedded ePortfolio learning and curation; and the recognition that ePortfolios are moving further away from simple electronic versions of resumes or showcase portfolios, and becoming more complex and flexible learning spaces for creators to save, collect, organise, design and share webpages for various and different audiences.

\section{History of the ePortfolio}

Dunbar-Hall, Rowley, Brooks, Cotton and Lill (2015) identify the introduction of ePortfolios to higher education as occurring in the 1990s as a replacement for paper-based portfolios. By 2005 the European Portfolio Initiatives Coordination Committee (EPICC) was describing an ePortfolio as a collection of student work stored in a digital format... (Jokinen, 2006, p.3). Since then, Parkes et al. (2013) state that while platforms for ePortfolios have changed, work with ePortfolios has been sustained [and] refined (p. 99). Across disciplines and throughout educational contexts, a need to collect evidence of learning has led to ePortfolios being a popular method of assessment. Traditional examinations test knowledge and at times allow students to provide application of that knowledge to a new situation. Text based assessment practices such as assignments and essays give the learner a space to display some analysis of the topic and to cite sources that support that analysis. Having progressed in educational practices there is now evidence to show that educators moving from these traditional measures of academic success are finding an electronic portfolio can also provide traditional accountability for student learning outcomes in assessments, as well as providing a rich source of evidence of deeper student thinking (Buyarski \& Landis, 2014). An ePortfolio allows students to take ownership of their learning by engaging in reflective thinking. Eynon and Gambino (2017) argue that allowing students to 'feel' ownership of their ePortfolio is a critical way to enhance student learning. These researchers and many others encourage students to use colour and images and allow them to have some capacity to design

ePortfolios are not only giving academic teachers the opportunity to have students evidence their achievement in specific disciplines, but are also engaging students to develop a narrative of their understanding of what and why they learnt a particular aspect of their discipline (Parkes, Dredger, \& Hicks, 2013). ePortfolios are consistently being used by teachers to ask students to evaluate their discipline learning and to reflect on how it impacts on who they are becoming professionally, and what they might look like in the future as a professional, as a result of that learning (Nakonechny \& Ellis, 2012). Today, ePortfolios are many different yet connected things: .... range of... models in practice... in creative arts and in medical science... promoting identity formation and supporting employability... a conveyance of a person's... professional genesis (Yancey, 2016, p. vi).

This gradual introduction of a new tool and thereby a new pedagogy into existing curriculums required a form of 'stake holding' from academic and educational staff which is reflected in the story of ePortfolios in Australian universities which emerged after a commissioned project in 2008 (Hallam, 2008). In 2012 Heinrich and Bozhko presented arguments that institutions in Australia and New Zealand were using ePortfolios to demonstrate they were promoting and supporting the importance of lifelong learning, but that learning support provided in higher education was still not sufficient. In 2017 yet another comprehensive look at the landscape of

Rowley, J. \& Munday, J, (2018). The evolved landscape of ePortfolios: Current values and purposes of academic teachers and curriculum designers. Journal of Teaching and Learning for Graduate Employability, 9(1), 3-22. 
ePortfolios in Australian universities showed the extent of the change referred to in this paper, and the broader need for building professional capabilities (Rowley, 2017, p. xiii).

International academics have noted the 'scene' for ePortfolio use in Australia through literature published in the first decade of the $21^{\text {st }}$ century (Ring \& Ramirez, 2012). At this time, Australian academics who were successfully using ePortfolios were also sharing their understandings through international conferences and platforms (Cambridge, 2010). Whilst it is beyond the scope of this paper to gauge the impact that Australian ePortfolio research and design is having internationally, it is clear that more Australian researchers are being published and cited in international journals (Cross, 2012; Hains-Wesson, Wakeling, \& Aldred, 2014; Rawlings, 2016; Munday, 2017; Munday, Rowley, \& Polly, 2017).

\section{Professional development needs of staff}

As noted in a short document published by the Australian ePortfolio network in 2009, applying the idea of an incremental introduction of any new pedagogy is better serviced when staff have been afforded training and resources (QUT, 2009). Higher education academics, teachers and learning designers are involved in designing and creating ePortfolio tools for different reasons (Callens \& Elen, 2007). Some tertiary teachers and designers are working with higher education students to enable the ePortfolio tool to collect evidence of learning and good practice over time prior to credentialing them into a profession (Gibson, 2006). Some are working with postgraduate students to enhance reflection and higher order thinking; and others need to create ePortfolios of their own to demonstrate abilities within their profession and to argue a case for promotion or leadership capabilities (Danowitz, 2012).

Winberg and Pallitt (2016) conducted a study with higher education staff working in vocational education to implement ePortfolios. The participants in their study were keen to learn, and valued the possibilities of using an ePortfolio in the future to apply for promotion or teaching awards. However, the study highlighted a number of problems for participants including the choice of ePortfolio platform, flexibility, and concern regarding possible institutional scrutiny of artefacts that might be presented to demonstrate abilities.

Professional development is an imperative if learning and teaching strategies are to be effective as it allows a person to focus on their craft by providing new ideas for further exploration of such skills. Eynon and Gambino (2016) suggest staff are being hindered in their desire to further develop good pedagogic practice because they are rarely given the opportunity to do so and building and sustaining a high-impact ePortfolio initiative depends on effective, pedagogy-focused professional development (p. 4). Why is it that educational institutions value pedagogic professional development below that of mastering learning technology systems? It is not the technology that hinders the attaining of excellence in ePortfolio practice; it is more likely to be the lack of opportunity for teachers to experience the powerful educational impact that the ePortfolio has the potential to provide. This is in line with the view of Eynon and Gambino (2016) as see in the following:

Professional development designed to advance high-impact ePortfolio practices can address a range of issues, from effective classroom teaching with ePortfolio to training on ePortfolio platforms, linkages with co-curricular learning or outcomes assessment, exploring disciplinary modes of inquiry and reflection, and making connections with other high-impact practices, such as first-year experience programs. It provides greater understanding of the broad usages of ePortfolio and connects faculty members and student life professionals in a concerted focus on student learning and growth (Eynon \& Gambino, 2016, p. 4).

It is clear from this quote that ePortfolio practices have the potential to address a range of emergent needs for staff in higher education. The barrier is often that staff have scant professional development and often have to rely on discovering the tool by themselves without the opportunity to experience an institutional wide approach to, and the benefits of, using

Rowley, J. \& Munday, J, (2018). The evolved landscape of ePortfolios: Current values and purposes of academic teachers and curriculum designers. Journal of Teaching and Learning for Graduate Employability, 9(1), 3-22. 
ePortfolio practices. To achieve the outcomes of the project explored in this paper it was necessary to identify key stakeholders in order to provide professional development workshops especially designed to empower the teachers who would introduce and or enhance ePortfolio use in their degree programs.

\section{As a complex and flexible learning space}

The need for a format or program that is robust and flexible enough to collect files of various types and formats has been an on-going difficulty as technologies change rapidly. Institutions have been exploring different products as ePortfolios move from being electronic versions of resumes to enhanced flexible and portable documents that are easily modified and updated (Halstead \& Wheeler, 2009). In reality, the digital space that ePortfolio provides allows for a greater exploration by higher education staff to show students how to carefully curate their learning collections. Hence, whatever technology is used to allow that method of learning to occur is somewhat irrelevant.

What is important is how and why the students use such a learning space to transfer individual experiences into authentic learning to assist them, amongst other things, in transitioning from student to professional. So much around the essence of ePortfolio thinking and processes involves reflective practice, and teaching staff without the correct understanding of the power of reflection can undersell the usefulness of ePortfolio learning. Through greater attention to the benefit of reflection, learners are able to value their experiences and gauge what those experiences mean to them personally. For students, taking ownership of their own learning and reflecting on that learning is a great skill to have when thinking about future careers. For staff, assisting the student to think critically about their futures can impact positively on the way curriculum is designed and implemented. Reflection is a portal through which the teaching and learning continuum can benefit all involved. Thus, staff engaging in reflective practice through professional development have the potential to promote enhancement of pedagogic skills. Eynon and Gambino (2016) see staff benefitting as reflective professional development deepens faculty and staff learning and helps them develop as practitioners (p. 6).

Encouraging students and staff to become reflective practitioners ensures that the ePortfolio is a user-friendly tool with a learning space for multiple purposes and users. Rogers (2002) proposed a model (Figure 1) of staff and student reflection that encouraged both learners to see beyond the transmission of facts and into a space of authentic learning and pedagogic practice.

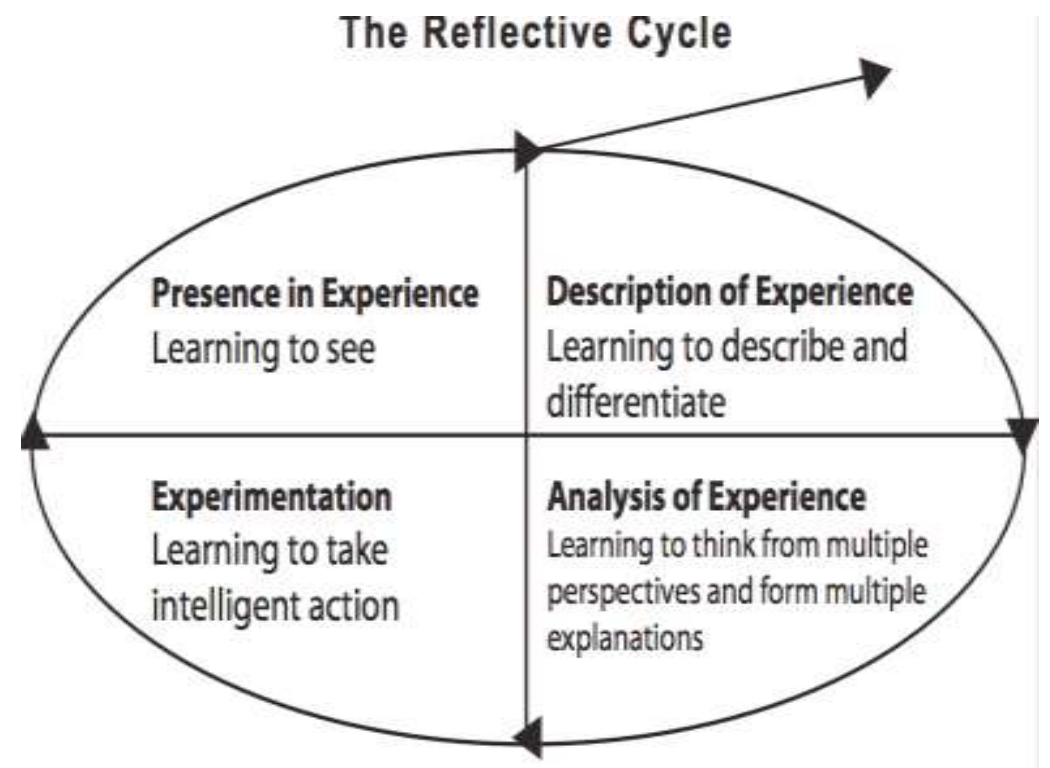

Figure 1: Rodgers Reflective Cycle (Rodgers, 2002, p. 235)

Rowley, J. \& Munday, J, (2018). The evolved landscape of ePortfolios: Current values and purposes of academic teachers and curriculum designers. Journal of Teaching and Learning for Graduate Employability, 9(1), 3-22. 
Reflection allows participants to connect experiences and integrate new knowledge (Eynon \& Gambino, 2016, p. 8). In a practical way, individual reflections can take many different forms and those that are in a digital space provide flexibility in for example oral, artistic, or multimedia reflections. The greater understanding of the reflective process, the better the teaching staff and curriculum designers could be at engaging students in meaningful learning experiences.

\section{The research project}

Along with a stable and flexible environment, some universities are beginning to establish professional development resources for academic faculty to promote reflective practice, critical thinking and support the introduction of ePortfolios into programs of study. Examples of professional development programs with structured outcomes around the complexity of ePortfolio learning are being designed and implemented in response to this growing need and the embedding of extended ePortfolios throughout degree programs (Eynon \& Gambino, 2016; Munday, 2014). The voices of staff interacting with ePortfolios within their teaching, curriculum and or learning designer role provides the evidence in this study for robust professional development for staff in tertiary institutions.

At the conclusion of the 2015 series of professional development webinars presented to those currently or intending to work with ePortfolios, the researchers were keen to enquire further into the practices of those who attended (OLT, 2016). Specifically, the interest was in knowing to what extent the processes of ePortfolios had been valued and used as teaching and learning tools. Also, the enthusiasm of the attendees and their interest in attending the sessions led to a consideration of why there was such a high level of uptake of the tool, or series of tools. Finally, the study investigated why staff sought the professional development webinars and workshops and volunteered for the survey and interview. Was this the result of their interest and commitment to the possibilities of ePortfolio or some other factors?

The question this paper aims to address through an exploration of the data from higher education staff who engaged with ePortfolio processes and products begins with: 'Is the ePortfolio part of a new literacy or is it that this technology tool is being better utilised?' This research aims to clarify whether or not this is, in fact, the case and suggests that as a tool promoting digital literacy, it has the potential to continue emerging for improved learning engagement. In addition, the research also aimed to determine whether academic teachers are more serious about the capacity of ePortfolios to engage learners and enhance the learning experience across a broader space than in the past. Discussions amongst the community of practitioners in Australia (for example at the annual ePortfolio Forum) encouraged this exploration. More specific research questions for this project were:

1. To what extent has the ePortfolio been valued and used as a teaching and learning tool by academic teachers and educational designers?

2. Why was there still a high level of uptake of the tool by designers of curriculum?

3. Why did staff seek the professional development webinars and workshops and volunteer for the survey and interview?

\section{Method and approach}

To explore these questions, a mixed method approach was applied including: a survey, designed and facilitated through Survey Monkey, and interviews with interested participants. Once ethical approvals were obtained through Charles Sturt University, potential participants were recruited via email from the 168 attendees at the webinar series. The survey responses were anonymous, and 47 were received. The survey included both quantitative and qualitative items (see Appendix).

Survey items were developed by researchers via field notes taken during the webinars on questions raised by participants in conjunction with the exploration of the literature on research

Rowley, J. \& Munday, J, (2018). The evolved landscape of ePortfolios: Current values and purposes of academic teachers and curriculum designers. Journal of Teaching and Learning for Graduate Employability, 9(1), 3-22. 
methods. From this, the researchers determined what they wanted to know, and therefore what questions to ask, and subsequently followed steps according to standard research methods (Artino, La Rochelle, Dezee, \& Gehlbach, 2014). Survey items were validated through trials with colleagues of the researchers. Feedback from the trial allowed the researchers to refine the survey before distribution. Survey items were designed to explore participants' depth and understanding of ePortfolios regardless of whether they were already users or intending to begin using ePortfolios. The 22 questions were designed to gather information about the broad use of ePortfolio products, applications and processes across a range of discipline areas. The survey particularly sought to gain a deeper understanding of the purpose and future directions of the ePortfolio tool by those in Australian higher education contexts.

Interview questions were developed by the researchers reflecting on data collected in the surveys and further refined after collegial feedback. Interviews were conducted by the researchers once participants volunteered to be interviewed on their survey form. Interviews were held via phone, Skype and in person with both researchers present in most cases - one interview was conducted with only one researcher present. The in-person interviews were held in the university offices of the researchers. If an interviewee agreed to be recorded then audio recordings were made of the interview and transcribed.

The survey aimed to clarify the participants' perceived value of the purposes of ePortfolios in Australian universities, and their views on the future directions for developing knowledge and learning. At the conclusion of the survey, participants were also asked if they were willing to be interviewed. Nine gave their contact details and all were interviewed. The interviews were conducted in person or by distance through phone or online, and ranged in length between 30 and 60 minutes. The interviews were transcribed to form the basis of the data analysed for this paper.

The responses to the interviews prompted the researchers to adopt a phenomenological perspective of the data where each response was considered within a narrative framework that positioned people's stories as a component of their personal social spheres (Connelly \& Clandinin, 1990) expressed in words, phrases and images. Following Dillon (2011), the narrative inquiry looked for processes of self-making (p. 213) by exploring personal meanings within, and commonalities and differences between experiences.

\section{Results and discussion}

Analysis of the interview data revealed that four main areas emerged: the first was that the definition of ePortfolios was broad, although very interesting. The second area that emerged was the prevalence of ePortfolio use being driven by the greater emergence of professional standards and requirements (for example, evidence of a competency) for these to be described and demonstrated. The third area was the satisfaction with the ePortfolio process and product in the students' learning lives. The final area was that the ePortfolio was most powerful as a learning tool when used for reflection, critical thinking and assessment.

\section{Survey Results}

Of the 47 surveys returned, none of the respondents identified as having no knowledge of ePortfolio and its processes, and 84 per cent rated themselves as having a good to very good understanding of an ePortfolio. The main disciplines reported in the surveys for the higher education programs were Education (58\%), Health Sciences (31\%), and Business Studies $(20 \%)$. Eighty-six per cent of respondents had used, or were intending to use ePortfolios with higher education students in degree programs. Most were using them for multiple purposes including: for assessment (92\%); for reflection (89\%); to showcase (76\%); and for 'development' (73\%). This is significant as it complements responses given by the nine interview participants. Other purposes that were reported were performance review, recognition of learning, developing digital competence, supervising of internships (as well as 
honours and master degrees), graduate employment, industry engagement, and collaboration.

Table 1: Responses to Questions 1, 4, 9, 10, and 17 ( $N=47)$

\begin{tabular}{lcc}
\hline Question & Frequency & Percent \\
\hline 1 & 41 & 84 \\
4 & 40 & 86 \\
9 - difficult & 23 & 51 \\
$10-$ difficult & 28 & 59 \\
$17-$ daily use & 8 & 18 \\
\hline
\end{tabular}

Table 1 provides a summary of the quantitative data supporting the divide between participants' opinions on the technology. Of those who completed the survey, on average, only 18 per cent were using ePortfolios daily. Also, 82 per cent of respondents said the platforms were easy to use, and 68 per cent agreed they were also easy for students to use. Seventy-eight per cent of the respondents were happy with the current university supported platforms. A number of commercial platforms were being used, including Pebble Pad, Mahara, Moodle, WordPress, Pathbrite, Blackboard, and Weebly.

The qualitative survey revealed that participants' definitions of an ePortfolio varied from very simple to very complex. Responses included, for example: collection of artefacts; an electronic repository where a person can collect a portfolio of their work and a powerful tool to capture learning and reflection. More complex notions included:

It's a chance to map and keep track of your professional development and growth over time. It enables you to collect, select, reflect and then connect evidence that you can digitally store and assemble differently according to your ever-evolving professional needs.

ePortfolio is a learning and teaching methodology suited to self-directed learning and professional development. I like the way it gives the learner space and freedom to explore, reflect, apply, synthesise and connect. It can handle ideas as well as facts. It is dynamic so that process as well as product can be evaluated. It supports a critical and reflexive approach to learning. It is deeply flexible in the way tasks can be tightly framed and scaffolded or left very fluid for the learner to play with aesthetic features and make the portfolio one's own.

A learner's structured collection of artefacts for particular purposes and audiences. These can include using ePortfolios to show the development of capabilities over time, providing evidence for validation of professional competencies, or to present exemplars of work for potential employers/clients.

Interview data

Nine participants agreed to be interviewed. The interview questions were semi-structured and were devised to provide further insight into the survey data. The interviews were recorded and transcribed. The interview data is presented under the four main areas that emerged during the analysis. 


\title{
Evolution to a broader definition of ePortfolio
}

The interviewer asked participants to provide their definition of an ePortfolio, whereas during the interviews participants talked about the features of the ePortfolios they were implementing within their degree programs and their added value in relation to other forms of assessment. One participant responded as follows:
A lot of our students don't even respond to lecturer or tutor feedback on assessments. So, the tendency to revisit learning and revisit the outcomes of one's learning is fairly scarce. If they're involved in ePortfolio, they actually have to, they can't finish the task. At [my university] ePortfolio tasks require them to revisit the learning opportunities and to make sensible informed connections and talk about how that learning relates to: things they already knew; things they've already done; things they've seen friends and family and colleagues and work mates do, if that's relevant; and also make connections between the specific discipline that they're asked to reflect on and all the other things they're studying in a formal sense. (Participant B: curriculum designer)

Several participants talked about earlier versions of ePortfolios being lists of items collected together in order to provide evidence of accreditation for a profession. This is supported by Hampe and Lewis (2013) who describe the ePortfolio as a place to record, store evidence of, and reflect on continuing activities, with the most challenging and least convincing aspect being the reflection. Some went on to describe how these had now developed into more useful documents with narratives which demonstrated reflection and reasoning:

\begin{abstract}
Historically in speech pathology, students had to complete a portfolio in the final year of the course and that seems like a box ticking exercise, very stressful and high stakes. Whereas my definition of success would be that students can look back over time and see their development over the whole of the courses and that the ePortfolio is the link between different units, the link between theory and practicum, helping to develop their competencies and integrate with all of their life more, develop reflection. At the moment, it's tied to one unit each semester, but I'm always thinking, how do I get them to make those links with other units as well? Are there ways to make them see it's bigger than one unit? It's the whole course. (Participant A: medical and health sciences)
\end{abstract}

Both Participants $A$ and $B$ are actively seeking ways to engage students in the processes of ePortfolios and make them increasingly valuable. They want to expand the use and place of ePortfolios within the degree program so that students can make connections that assist them to narrate or reflect on such new linkages. Likewise, Connaughton and Edgar (2012) considered the value of reflection yet sought to find the relevance of reflection in current work practices - their study showed that reflective practice was enhanced over the course of a degree program.

\section{ePortfolio and professional standards}

In the past, especially in the early introduction of ePortfolio use, professional standards provided a list of skills students could present to a future employer. Parkes et al. (2013) recognised the previous compilation of artefacts for ePortfolios, yet proceeded to describe the move towards ePortfolios as a 'pedagogical space' for developmental reflection (p.99). In this research, academic teachers are encouraging pre-service professionals to weave a narrative around standards and are devising curriculum to help them provide a compelling argument for future employment as seen in the following comment:

The moment they start their undergraduate degree (as in O week) we are asking them to consider the skills they bring to the pre-professional study. We are already helping them understand they are on their way to becoming a member of the profession. We also ask them to find an image as a metaphor or symbol of themselves as teachers

Rowley, J. \& Munday, J, (2018). The evolved landscape of ePortfolios: Current values and purposes of academic teachers and curriculum designers. Journal of Teaching and Learning for Graduate Employability, 9(1), 3-22. 
or pre-service teachers - we ask them to do this again at the end of the degree and the change is really evident, and they are able to talk about their change of thinking and the way they've developed which makes them ready to step into the profession. (Participant C: teacher education)

The advancement of the online platform means that students are able to collect evidence and data over a long period and create sharable and engaging documents that link to their collection rather than expect viewers (usually the teaching staff) to trawl through lists and files. Not only are there purpose-built ePortfolio programs being provided to students and staff by higher education institutions, but other internet tools are also being used that are freely available, albeit without privacy, security, and advertising (Weber \& Evans, 2011; Gross, 2012) as seen in the following:

So, we're using Pebble and they can export it. They use workbook and the workbook they have is massive and employers are never going to look at it! We talked about how you could cherry pick your best pieces of evidence, make a showcase ePortfolio with just one page with hyperlinks in it, that would be tailored to the application that you're making and how you might put that link in your cover letter, and even if they never looked at it, they would be impressed that you had done something like that, and give you the edge. (Participant A: medical and health sciences)

...and I can imagine as an employer I would be thinking, 'Wow, compared to your contemporaries, you stand out!' If you're looking for that one person in 1000 people and they've got an ePortfolio, they're going to get the job, they're going to get the scholarship, and they're going to get the gig. (Participant D: science)

Participants $A, C$ and $D$ all encouraged their students to collect as much evidence of their achievements as they could and scaffolded for their students how to choose items appropriate to the reader or viewer of the ePortfolio. Even though a collection of assets or artefacts is large, the ePortfolio tool is flexible enough for narratives to be created specifically for an individual's needs or requirements. In the early introduction of ePortfolios, some researchers observed student and staff resistance to the volume of work required in learning to use the ePortfolio platform (Butler, 2006), but recent research, along with several of the interviewees, claim that the purposeful nature of the ePortfolio and the recognition for academic support and resolving of workload issues heralds a change to these problems (McAllister \& Hauville, 2017).

\section{ePortfolio processes and products embedded in professional life and practice}

Several of the academic teachers who were interviewed talked about creating their own ePortfolios as they were designing them for their students - both for the virtues they were modelling for students and to explore their uses for their own professional work and identities as they applied for promotion or tenure (Cambridge, 2012):

...oh crikey, am I doing it right? And after a while it became a lot easier to do it, and also because I was thinking in terms of that I would need to present a showcase later on, there was lots of sorts of tips and tools and opportunities for me to look at other showcases around the world and decide for myself what is good, and from that I could see it would be a really powerful way of presenting the person that you really are, which is a lot different I find to a very dimensional Linkedln profile that a lot of people have. (Participant D: science)

...my leadership portfolio, the first ePortfolio. Then I just tailored the CV to the role that I was going for, and tweaked that a bit for the level 9 role that I was going for, and it was really the only two changes that I made, and then I just put my links in my expression of interest with a password, because the selection panel could log on,

Rowley, J. \& Munday, J, (2018). The evolved landscape of ePortfolios: Current values and purposes of academic teachers and curriculum designers. Journal of Teaching and Learning for Graduate Employability, 9(1), 3-22. 
because the selection panel were [my university] staff members, so they were able to log into the ePortfolio page that links the selection criteria. (Participant D: science)

In learning, how to create her own ePortfolio for her own professional needs, Participant D was able to present herself as a model to her students and embody all the advantages the advanced tool provides. During the professional development sessions and webinars participants were encouraged to create their own ePortfolios, not only to model good practice to students and colleagues, but also to encourage academics, curriculum and educational designers to engage in their own evidence gathering regarding their growth and competency. The interviewees who had created their professional ePortfolios noted the work involved, but acknowledged the resulting value the portfolio had in their career promotions (Winberg \& Pallitt, 2016)

\section{Expanded purposes of ePortfolio}

As previously mentioned the technology in the online space has advanced and ePortfolio platforms have become more flexible, enabling the owner to be more creative. The survey asked participants if they used ePortfolio for reflection, assessment, development and showcase (Stefani, Mason, \& Pegler, 2007). These were all very highly valued processes for the ePortfolio, but respondents noted many more uses and explained in the interviews how complex an ePortfolio could be, allowing the demonstration of other examples of higher order thinking processes, as is demonstrated in the quotes below:

We're getting them to think about what do they know, what skills have they already developed in their wider life, and how does that relate to the competencies of being a speech pathologist. And I think the ones that do really well in the ePortfolio, they're really seeing how everything they've done in their life has led them to this point, the skills they've already developed, the interests that they already have, which is that integrative learning stuff, they can see how that is leading them to this career choice. (Participant A: medical and health sciences)

Because you set a task that wants critical analysis, and imagination, originality, and or course you have to do a rubric. And then they refer to elements of the rubric as actually question items: Question one, provide an introduction, question two... They look at it as discrete blocks of question-answer format which is the very thing I'm trying to get away from, to get them to think more holistically and critically and practically. So, it's this specifying the task, but getting them to tap into their own knowledge, their own mental model and experience. (Participant E: business management)

ePortfolios are useful for life skills. They encourage development of confidence in writing and curating, whilst also helping emerging professionals to have a voice about the career and their learning to 'be'.' (Participant F: teacher education)

The above examples all emphasise the vocational nature of the higher order thinking skills that ePortfolios afford. Participant E, in particular, articulated the tension between the earlier 'tick-a-box' mentality of assessment versus the non-academic skills stated in each example, which employers say are crucial to the professions (Cambridge, 2010).

\section{Evolution toward career relevance}

After analysing both the survey and interview data, several key issues were noted that demonstrate the changed landscape of ePortfolio use and design. There appeared to be increased use of ePortfolios in the higher education institutions, and the participants in the study, as academic teachers and curriculum designers, were becoming more skilled at implementing them. The accountability noted in the Background section of this paper is

Rowley, J. \& Munday, J, (2018). The evolved landscape of ePortfolios: Current values and purposes of academic teachers and curriculum designers. Journal of Teaching and Learning for Graduate Employability, 9(1), 3-22. 
focussed on assessments to demonstrate the preparation of graduates for future careers. All of the interviewees emphasised the value of the ePortfolio for raising the consciousness of the students to the need to impress potential employers and to collect evidence of achieving professional standards or competencies. In the following quote, we can see the value of an embedded ePortfolio where students argue their abilities throughout the degree program:

They have already written about it and thought about it every year for four years, so they have got a really clear way of articulating it in a way that makes sense to employers... they're always setting goals for the next semester as well. So, they're thinking about how they've shown it and where they're going to go for the next step. And at the end of four years, they set goals for their first job. (Participant A: medical and health sciences)

The more complex nature of the ePortfolio along with the emergence of embedded designs (where students continued to collect evidence of development and achievement) has influenced assessment practices of teaching staff. In addition, the students, or pre-service professionals are more intrinsically motivated to create more personalised and interesting documents for prospective viewers. Ring and Ramirez' assertion (2012) that portfolio assessment provides multiple benefits for both the developer and the institution in the form of valid, holistic assessment... (p.91) was reinforced by interviewees and through the evidence provided in the qualitative definitions of the survey participants:

But being forced to do it for assessment, and this fits with motivation literature as well, that if you are forced from an extrinsic perspective to undertake a task multiple times, you are more likely to develop an intrinsic satisfaction for what you are doing than if you were never engaged in the first place. (Participant B: curriculum designer)

The interviewees mentioned the continued engagement with the ePortfolio and varied processes of ePortfolio. As designers of ePortfolio learning and assessment the academic teachers talked about ways to further engage students in thinking about their future profession and how they are differentiating themselves personally and professionally:

... and getting them to think about 'what evidence have I got that shows I'm developing my competency?' and they have to assess themselves mid and end compass with a clinical educator. There's an assessment as well. I think that gathering that information and thinking about that information really helps them understand how 'I'm linking what l'm learning in the theory and applying it to practice'. (Participant A: medical and health sciences)

Participants appeared to value the ePortfolio for its increasing flexibility. As was noted in the literature review, there has been a need for more flexible and robust platforms for creating, maintaining and sharing ePortfolios, so participants were asked which platforms they used. Ring and Ramirez (2012) discuss flexibility from both the academic teacher point of view for assessment as well as the student viewpoint with regard to the technology or the platform. Several of the interviewees gave examples of students using their ePortfolio beyond the work they were doing in their degree programs:

And sometimes you get to talk to students who use it while they're at [my university] to get a job at McDonalds or as a barista or something... (Participant B: curriculum designer)

And so, it's useful for understanding self, useful for understanding not only what you've learnt by how you've learnt, and understanding who you are in multiple capacities. Because students say 'I can use this for so many different things. I can see how l'd use it for getting a weekend job. I can see how I would use it when

Rowley, J. \& Munday, J, (2018). The evolved landscape of ePortfolios: Current values and purposes of academic teachers and curriculum designers. Journal of Teaching and Learning for Graduate Employability, 9(1), 3-22. 
addressing selection criteria. And I want to share it with my family and friends and

get them to tell me what they think'. (Participant B: curriculum designer)

For the last two specific research questions the study aimed to address, it appears the continued uptake of the ePortfolio and the voluntary involvement in professional development webinars and workshops may be attributed to the maturing and evolved nature of the ePortfolio. The ePortfolio learning design is more complex because the tool has more possibilities for demonstrating and providing evidence for complex and higher order thinking skills. McAllister and Hauville (2017) discuss an ePortfolio program that began in 2004 and through the growth in understanding of the capabilities of the tool and its progressive embedding in units and courses conjures many different understandings and is a program comprising the process of critical reflection or critical self-enquiry... (p. 15). Similar comments were made by one participant:

\begin{abstract}
...you've got the portfolio as a methodology - I like to think of it as a methodology. You know how in research - I'm really into epistemology and all that sort of stuff. You know some people talk about methodology in terms of methods, and I find that really superficial. People who are really solid researchers really talk about methodology in terms of the strong connection between your ontology and your epistemology and your methodology and that it all fits. (Participant $\mathrm{E}$ : business management)
\end{abstract}

The comparison to research methods in the above quotation reinforces the more complex nature of the ePortfolio today - as both a literacy tool and a learning strategy that is being better used. In research, there are complicated processes of experimentation or exploration. Likewise, the ePortfolio now has the attributes of being more complicated and allowing the owner to make connections between reflective and developmental processes that in the past might not have been possible. As in research, the collected artefacts in an ePortfolio may be collated and re-sorted to present new knowledge. However, we have concluded through the survey and interview responses presented here in this paper that it is new knowledge of a personal or professional kind being used more competently - a higher knowledge of the 'sense of self' or 'sense of professional self' (Rowley \& Munday, 2014).

\title{
Conclusion
}

From the data analysis it is apparent that curriculum designers, academic teachers and others who completed the survey and/or were interviewed, were able to articulate what they had learned about ePortfolio processes, benefits and potential uses. The research study sought an answer to the question: Is ePortfolio part of a new literacy or is it that this technology tool is being better utilised? This question was intentionally provocative to keep the conversation moving forward inside the world of portfolio development and digital literacies. It is evidenced here that the results of this investigation provide testimony from staff that the ePortfolio had moved from being a 'one-off' novelty to an embedded teaching and learning tool that is being used in a multi-disciplinary way.

Evidence of a maturing of the users, specifically the academic educators and curriculum designers, indicates a move from traditional to contemporary approaches in the use of ePortfolios; students are now carefully designing a narrative or story around who they are becoming as a result of their discipline studies rather than a list of achievements. The survey data in particular showed the capacity of the ePortfolio space to be more robust as a part of the evidence of learning. Participants' responses demonstrated that the range of skills required of learners has grown in recent times, making the $21^{\text {st }}$ century learner and learning space more authentic, and digital literacy has become an expectation. Skills developed during the creation of an ePortfolio assist students to transition away from scaffolded learning to a more independent means of exploring their own professional future work and identity.

Rowley, J. \& Munday, J, (2018). The evolved landscape of ePortfolios: Current values and purposes of academic teachers and curriculum designers. Journal of Teaching and Learning for Graduate Employability, 9(1), 3-22. 
In response to the specific research questions, the evidence from this study indicates that the landscape is changing and that ePortfolios are used more often in the contemporary higher education environment than in the past. Furthermore, curriculum designers are constructing more complex and appropriate learning strategies for students during undergraduate study. 


\section{References}

Artino, A.R., La Rochelle, J.S., Dezee, K.J., Gehlbach, H. (2014). Developing questionnaires for educational research: AMEE Guide No. 87. Med Tech 36(6), 463-474.

doi: 10.3109/0142159X.2014.889814

Butler, P. (2006). A review of the literature on portfolios and electronic portfolios (ePortfolios). Accessed from http://akoaotearoa.ac.nz/download/ng/file/group-996/n2620eportfolio-research-report.pdf

Bennett, D., Rowley, J., Dunbar-Hall, P., Hitchcock, M., \& Blom, D. (2016). Electronic portfolios and learner identity: An ePortfolio case study in music and writing. Journal of Further and Higher Education, 40(1), 107-124. doi:10.1080/0309877X.2014.895306

Boesch, B., Reynolds, C., \& Patton, J. (2016). ePortfolios as a tool for integrative learning: Building classroom practices that work. In E. Railean, G. Walker, A. Elçi, \& L. Jackson (Eds.), Handbook of research on applied learning theory and design in modern education (pp. 439-464). Hershey, PA: IGI Global. doi:10.4018/978-1-4666-9634-1.ch021

Buyarski, C., \& Landis, C. (2014). Using an ePortfolio to assess the outcomes of a first-year seminar: Student Narrative and Authentic Assessment. International Journal of ePortfolio 4(1), 49-60. ISSN 2157-622X

Callens, J., \& Elen, J. (2007). Purpose and design of an ePortfolio. Conference ICL2007, September 26-28, 2007, Vilach, Austria. Kassel University Press.

Cambridge, D. (2010). Eportfolios for lifelong learning and assessment. Retrieved from https://ebookcentral-proquest-com.ezproxy.csu.edu.au

Cambridge, D. (2012). E-Portfolios and global diffusion: Solutions for collaborative education. IGI Global.

Connaughton, J., \& Edgar, S. (2012). What is the relevance of reflective practice in undergraduate e-portfolios to professional work practices? Australian Collaborative Education Network (ACEN Inc.) Conference Proceedings. Melbourne/Geelong. Retrieved from: http://acen.edu.au/2012conference/wp-content/uploads/2012/11/61 What-is-therelevance-of-reflective-practice-in-undergraduate-e.pdf

Connelly. M., \& Clandinin, D. (1990). Stories of experience and narrative inquiry. Educational Researcher, 19(5), 2-14. https://doi.org/10.3102/0013189X019005002

Cross, J. (2012). From the reflective ePractitioner: A pilot model of teacher preparation employing ePortfolio. International Journal of ePortfolio (2)1, 39-48. ISSN: 2157-622X

Danowitz, E. (2012). On the right track: Using ePortfolios as tenure files. International Journal of ePortfolio (2)1, 113-124. ISSN 2157-622X

Dillon, L. (2011). Writing the self: The emergence of a dialogic space. Narrative Inquiry, 21(2), 213-237. http://dx.doi.org/10.1075/ni.21.2.03dil

Dunbar-Hall, P., Rowley, J., Brooks, W., Cotton, H., \& Lill, A. (2015). E-portfolios in music and other performing arts education: History through a critique of Literature. Journal of Historical Research in Music Education, (36)2, 139-154.

https://doi.org/10.1177/153660061503600205

Eynon, B., \& Gambino, L. (2017). High-impact ePortfolio practice: A catalyst for student, faculty, and institutional learning. Stylus Publishing, 256 pages. ISBN-13: 9781620365045. Accessed 11/11/17:

https://books.google.com.au/books?id=f2HmDQAAQBAJ\&printsec=frontcover\#v=onepag $\underline{\mathrm{e} \& q \& \mathrm{f}=\mathrm{false}}$

Eynon, B., \& Gambino, L. (2016). Professional development for high-impact eportfolio practice. Peer Review, (18)3. Association of American Colleges \& Universities (AAC\&U). https://www.aacu.org/peerreview/2016/summer/Eynon 
Gibson, D. (2006). ePortfolio decisions and dilemmas. In A. Jafari \& C. Kaufman (Eds.), Handbook of research on ePortfolios (pp. 135-145). Hershey, PA: IGI Global.

Doi:10.4018/978-1-59140-890-1.ch014

Gross, J. (2012). Building your library career with Web 2.0. Woodhead Publishing Limited.

Hains-Wesson, R., Wakeling, L., \& Aldred, P. (2014). A university-wide ePortfolio initiative at Federation University Australia: Software analysis, test-to-production, and evaluation phases. International Journal of ePortfolio (4)2, 143-156. ISSN 2157-622X

Hallam, G. (2008). The Australian ePortfolio project and the opportunities to develop a community of practice. In Hello! Where are you in the landscape of educational technology? Proceedings ascilite Melbourne, December 2008.

http://www.ascilite.org.au/conferences/melbourne08/procs/hallam.pdf

Hampe, N., \& Lewis, S. (2013). E-portfolios support continuing professional development for librarians. The Australian Library Journal (62)1, 3-14, DOI: 10.1080/00049670.2013.771766

Halstead, A., \& Wheeler, L. (2009). Enhancing reflective professional practice through the use of an ePortfolio: A UK case study. In Same places, different spaces. Proceedings of ascilite. Auckland, December 2009.

http://www.ascilite.org.au/conferences/auckland09/procs/halstead.pdf

Heinrich, E., \& Bozhko, Y. (2012). The role of institutions in creating student-focused virtual learning spaces with ePortfolio systems. In M. Keppell, K. Souter, \& M. Riddle (Eds.), Physical and virtual learning spaces in higher education: Concepts for the modern learning environment (pp.119-135). Hershey, PA: IGI Global. Doi: 10.4018/978-160960-114-0.ch008

Herring, D., \& Notar, E. (2011). Show what you know: ePortfolios for $21^{\text {st }}$ century learners. College Student Journal, (45)4, 786-792. ISSN: 0146-3934

Jokinen, T. (2006). About ePortfolios - practise, history and different ways of using them. EPICC Final Report: http://www.eife-

I.org/activities/projects/epicc/final_report/WP3/EPICC3_9_Portfolios\%20in\%20Finland.pdf

McAllister, L., \& Hauville, K. (2017). Striving for sustainability: ePortfolio pedagogy in Australian Higher Education. In J. Rowley (Ed.), ePortfolios in Australian universities (pp.13-32). Springer: ISBN: 978-981-10-1731-5.

Munday, J. (2017). An embedded ePortfolio in a master's degree: Is it working? International Journal of ePortfolio (7)2, 175-185. ISSN 2157-622X

Munday, J. (2014). Taking their skills with them: Seeking to find out whether ePortfolio skills transfer from degree programs to the classroom. In A. Poot (Ed), Pebble Pad: Personalising the curriculum (pp. 5-15). Telford, Pebble Learning Ltd. http://www.pebblebash.co.uk/2014/Resources/pdf/pb2014rp01.pdf

Munday, J., Rowley, J., \& Polly, P. (2017). The use of visual images in building professional self identities. International Journal of ePortfolio (7)1, 53-65. ISSN 2157-622X.

Nakonechny, J., \& Ellis, S. (2012). Bryofolios: Individual and group e-oortfolio learning spaces for developing authentic science scholars. In, D. Cambridge. (Ed.), E-portfolios and global diffusion: Solutions for collaborative education (pp. 29-40). IGI Global.

Office for Learning and Teaching (OLT). (2016). ePortfolios for creative arts, music and arts students in Australian universities. ID11-2041 Final Report. ISBN: 978-1-76028-688-0.

Parks, K., Dredger, K., \& Hicks, D. (2013). ePortfolio as a measure of reflective practice. International Journal of ePortfolio, (3)2, 99-115. ISSN 2157-622X

Pegrum, M., \& Oakley, L. (2017). The changing landscape of e-portfolios: Reflections on 5 years of implementing e-portfolios in pre-service teacher education. In T. Chaudhuri \& B. Cabau (Eds.), E-portfolios in higher education, (pp.21-34). Springer Nature. Singapore. doi: 10.1007/978-981-10-3803-7_2

Rowley, J. \& Munday, J, (2018). The evolved landscape of ePortfolios: Current values and purposes of academic teachers and curriculum designers. Journal of Teaching and Learning for Graduate Employability, 9(1), 3-22. 
QUT Publications. (2009). ePortfolio concepts for academic staff. Accessed 11/11/17: http://www.eportfoliopractice.qut.edu.au/docs/AeP conceptguide academic staff.pdf

Rawlings, J. (2016). The use of e-portfolios in music teacher education programs: 20032013. Contributions to Music Education, 41, 53-69. Retrieved from https://searchproquest-com.ezproxy.csu.edu.au/docview/1790516777? accountid=10344

Ring, G., \& Ramirez, B. (2012). Implementing ePortfolios for the assessment of general education competencies. International Journal of ePortfolio, (2)1, 87-97. ISSN 2157$622 X$

Rodgers, C. (2002). Voices inside schools seeing student learning: Teacher change and the role of reflection. Harvard Educational Review, 72(2), 230-253. DOI: 10.17763/haer.72.2.5631743606m15751

Rowley, J. (2017). ePortfolios in Australian Universities. Springer.

Rowley, J., \& Munday, J. (2014). A 'sense of self' through reflective thinking in ePortfolios. International Journal of Humanities Social Sciences and Education (1)7, 78-85. ISSN 2349-0373

Stefani, L., Mason, R., \& Pegler, C. (2007). The educational potential of e-portfolios: Supporting personal development and reflective learning. London: Routledge.

Wakimoto, D. K., \& Lewis, R. E. (2014). Graduate student perceptions of eportfolios: Uses for reflection, development, and assessment. The Internet and Higher Education, 21, 53 58. doi: 10.1016/j.iheduc.2014.01.002

Weber, I., \& Evans, P. (2011). $E=$ Mportfolios $^{2}$ ? Challenges and opportunities in creating mobile electronic portfolio systems for lifelong learning. International Journal of Web Portals 3(2), 1-13. DOI: 10.4018/978-1-4666-2779-6.ch005

Winberg, C., \& Pallitt, N. (2016). 'I am trying to practice good teaching': Reconceptualizing eportfolios for professional development in vocational higher education. British Journal of Educational Technology (47)3, 543-553. doi: 10.1111/bjet.12440

Yancey, K. (2016). Foreword: What we learn from this portfolio collection. In, J. Rowley (Ed.), ePortfolios in Australian universities. Springer. (pp. i-iv). Springer: ISBN: 978-98110-1731-5. 


\section{Appendix}

\section{Survey Questions: Making ePortfolios Relevant: Developing a Professional Identity.}

1. How would you rate your understanding of what an ePortfolio is? (Very poor; Poor; OK; Good; Very Good):

2. In your own words, please define your understanding of an ePortfolio:

3. Have you used paper-based portfolios with higher education students? (Yes; No):

4. Have you used electronic portfolios with higher education students? (Yes; No):

5. Do you feel that electronic portfolios could be useful in your future curriculum design? Please describe how, or if not, why not:

6. In which discipline area(s) have or do you use ePortfolios? (You may select more than one if applicable) (Education; Nursing; Midwifery; Business Studies; Journalism; Psychology; Philosophy; Social Science; Environmental Science; Veterinary Science; Other [please specify]):

7. For what purpose(s) have or do you use ePortfolios? (You may select more than one if applicable). (Assessment; Development; Reflection; Showcase; Other [please specify]):

8. What product/application do you currently use for ePortfolios?

9. Please comment on the ease of use of this product/application for you own use. (Very difficult; Difficult; Easy; Very easy):

10. Please comment on the ease of use of this product/application for your students. (Very difficult; Difficult; Easy; Very easy):

11. Please list the features that you feel are most difficult:

12. Please list the features that you feel are most useful:

13. Have you used other ePortfolio products/applications prior to the one you are currently using?

14. What other ePortfolio products/applications have you used?

15. Please give a brief description or explanation of any particular issues that caused you to change to the product/application you are currently using:

16. In your opinion, what features should an ePortfolio platform include?

17. During the past year, how often would you have accessed the ePortfolio space provided by the university? (Never; Occasionally (2-3 times); Sometimes (4-10 times); Often (more than 10 times); Almost daily):

18. Please rate your experience of the ePortfolio provided by the university over the past year. (Mostly positive; Somewhat positive; Equal positive and negative; Somewhat negative; Mostly negative):

19. Please indicate your level of agreement or disagreement with the following statements: The ePortfolio learning is well integrated with weekly learning. (Strongly disagree; Disagree; Neither agree nor disagree; Agree; Strongly Agree); ePortfolio activities encourage active learning; I can see evidence of student reflection and 
development through ePortfolio; My students can gain feedback from their peers through ePortfolio; I provide resources and templates through the ePortfolio space.

20. Which areas of students' learning are affected through their use of ePortfolio, and to what extent? (Personal and intellectual; Research and inquiry; Communication; Ethical, social and professional understanding):

21. Please indicate your level of agreement or disagreement with the following statements: The ePortfolio in the degree program is influenced by professional standards (Strongly disagree; Disagree; Neither agree nor disagree; Agree; Strongly Agree); The ePortfolio in the degree program can be shared with prospective employers; The possibility of an employer viewing the portfolio has influenced the design of the collection and curation of the ePortfolio; Students nearing graduation have opportunities to present and share ePortfolios with prospective employers.

22. Please add any further comments you have about ePortfolios and their use.

23. Would you be willing to participate in a 30-60 minute individual interview about your experiences of and/or plans for an ePortfolio?

24. Thank you for indicating you are willing to participate in an interview. Please provide your email address so we can contact you to arrange a suitable date and time. 


\section{Interview Questions for ePortfolio Survey Respondents}

This interview follows the survey about making ePortfolios relevant and we ask you to reflect on your survey responses. The final question on the online survey asked you to 'add any comments you have about ePortfolios and their use':

1. In what ways do you see ePortfolios as a useful learning tool that benefits learning?

2. We are curious about the development of professional identity and the connection between the ePortfolio and identity development. How do you think the ePortfolio assists the learner to develop their professional identity?

3. The ePortfolio is reported to assist students with their engagement in learning. To what extent do you think the ePortfolio engages students? Maybe give an example.

4. Students are extrinsically motivated to prepare an ePortfolio as it is embedded or there is an assessment task associated with it. What do you believe are or could be the intrinsic motivations for developing a portfolio?

5. Portfolios are primarily private learning spaces and often the development of a personal ePortfolio goes through stages before it becomes a showcase or public space. In your opinion, what is the potential for the portfolio to be both a tool for personal identity development and a tool for professional identity development? Give examples.

6. It is often reported that ePortfolio success will only be attained if it is scaffolded. Can you describe your view for success of an ePortfolio?

7. After considering all that you've told us, what other purposes do you believe ePortfolios are useful for? Why?

8. What did you think is the hardest thing about creating an ePortfolio? Why?

9. Is there anything else from your experience of working with, or creating, ePortfolios that you would like to tell us? 